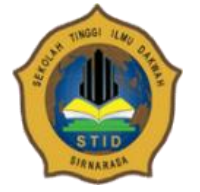

IKTISYAF

Volume 2, Nomor 1, 2020 halaman 13-23

Sekolah Tinggi Ilmu Dakwah (STID) Sirrnarasa

\title{
BIMBINGAN PRA NIKAH DALAM MBENTUKAN KELUARGA SAKINAH
}

\author{
Witrin Noor Justiatini, Muhammad Zainal Mustofa \\ Bimbingan Penyuluhan Islam STID Sirnarasa \\ Witrin@stidsirnarasa.ac.id.
}

\begin{abstract}
ABSTRAK
Pernikahan adalah upacara pengikatan janji nikah yang dirayakan atau dilaksanakan oleh dua orang dengan maksud meresmikan ikatan perkawinan secara norma agama, norma hukum, dan norma sosial. Upacara pernikahan memiliki banyak ragam dan variasi menurut tradisi suku bangsa, agama, budaya, maupun kelas sosial. Penggunaan adat atau aturan tertentu kadangkadang berkaitan dengan aturan atau hukum agama tertentu pula. Secara rasionalis rumah tangga begitu mudah dipahami, berbeda dengan praktik yang kadang jauh dari prasangka sebelumnya.

Teori yang digunakan dalam penelitian ini menggunakan teori yang disampaikan oleh Prayitno, bimbingan adalah proses pemberian bantuan yang dilakukan oleh orang yang ahli kepada seorang atau beberapa orang individu, baik anak-anak, remaja, maupun dewasa; agar orang yang dibimbing dapat mengembangkan kemampuan dirinya sendiri dan mandiri; dengan memanfaatkan kekuatan individu dan sarana yang ada dan dapat dikembangkan; berdasarkan norma-norma yang berlaku.Tujuan penenlitian ini Untuk mengetahui bagaimana proses pelaksanaan Bimbingan Konseling Pranikah calon pengantin di KUA Kecamatan Panjalu dan Bagaimana hasil akhir juga dampak dari proses pelaksanaan Bimbingan Konseling Pranikah dalam membentuk keluarga sakinah di KUA Kecamatan Panjalu. Metode yang digunakan dalam penelitian ini adalah metode penelitian kualitatif, sedangkan pendekatan menggunakan study fenomenologi yang mengungkapkan berbagai peristiwa dalam ranah penelitian yang bertempat di KUA panjalu. Berdasarkan hasil penelitian tentang bimbingan pranikah dalam membentuk keluarga sakinah di KUA Kecamatan Panjalu Kabupaten Ciamis, maka peneliti dapat mengambil kesimpulan sebagai berikut: Bimbingan Pranikah dalam membentuk keluarga Sakinah di KUA Kecamatan Panjalu terbagi menjadi dua bentuk yaitu bimbingan secara individu dan kelompok, akan tetapi bimbingan pranikah individu tidak efektif di karenakan calon pengantin tidak langsung mendaftar ke KUA akan tetapi di urus langsung oleh petugas dari desa yaitu (Petugas Pembantu Pencatat Nikah) P3N.
\end{abstract}

Kata kunci: Bimbingan, Keluarga Sakinah

\begin{abstract}
Marriage is a ceremony to tie a marriage promise which is celebrated or carried out by two people with the intention of formalizing the marriage bond according to religious norms, legal norms and social norms. Wedding ceremonies have many varieties and variations according to ethnic, religious, cultural and social class traditions. The use of certain customs or rules is sometimes related to certain religious rules or laws. Household rationalists are easy to understand, different from practices that are sometimes far from previous prejudices.The theory used in this study uses the theory presented by Prayitno, guidance is the process of providing assistance by an expert to one or several individuals, both children, adolescents, and adults; so that the person being guided
\end{abstract}


can develop their own abilities and independently; by making use of individual strengths and existing and expandable means; based on prevailing norms. The purpose of this research is to find out how the process of implementing the Prenuptial Counseling Guidance for the bride and groom in the KUA Panjalu District and how the final result is the impact of the process of implementing Prenuptial Counseling in forming a sakinah family in the KUA Panjalu District. The method used in this study is a qualitative research method, while the approach uses a phenomenological study which reveals various events in the realm of research that took place at KUA Panjalu. Based on the results of research on premarital guidance in forming a sakinah family in KUA, Panjalu District, Ciamis Regency, the researchers can draw the following conclusions: Prenuptial guidance in forming a Sakinah family in KUA Panjalu District is divided into two forms, namely individual and group guidance, but prenuptial guidance. Individuals are ineffective because the prospective bride and groom do not register directly with the KUA but are taken care of directly by a village official, namely (Marriage Registration Assisting Officer)

\section{Keywords: Guidance, Family Sakinah}

\section{PENDAHULUAN}

Pernikahan adalah upacara pengikatan janji nikah yang dirayakan atau dilaksanakan oleh dua orang dengan maksud meresmikan ikatan perkawinan secara norma agama, norma hukum, dan norma sosial. Upacara pernikahan memiliki banyak ragam dan variasi menurut tradisi suku bangsa, agama, budaya, maupun kelas sosial. Penggunaan adat atau aturan tertentu kadang-kadang berkaitan dengan aturan atau hokum agama tertentu pula.

Pernikahan menurut Thalib adalah suatu bentuk perjanjian suci yang amat kuat dan kokoh untuk hidup bersama yang sah diantara laki-laki dan perempuan, sehingga diharapkan dari keputusan itu mampu membentuk keluarga yang kekal, saling santun menyantuni, saling kasihmengasihi, tentram, dan juga bahagia.

Mempunyai keluarga sakinah adalah idaman setiap orang. Kenyataan ini menunjukan banyak orang yang merindukan dalam rumahtangganya menjadi sesuatu yang teramat indah, bahagia, penuh dengan berkah yakni keluarga sakinah mawaddah wa rahmah. Dalam kehidupan rumah tangga tidak sedikit dari keluarga yang hari demi harinya hanyalah perpindahan dari kecemasan kegelisahan, dan penderitaan. Bahkan tidak jarang diakhiri dengan kenistaan, perceraian, dan juga derita.

Banyak problema yang biasa dihadapi dalam sebuah keluarga. Tidak sedikit keluarga yang menyerah atas "derita" yang sebetulnya diciptakannya sendiri. Di antaranya memilih perceraian sebagai penyelesaian. Kasus-kasus faktual tentang itu semuanya ada di masyarakat kita. Dan, masih banyak lagi kegelisahan yang melilit dalam keluarga di masyarakat. Namun, umumnya kegelisahan itu diakibatkan oleh menurunnya kemampuan mereka menemukan alternatif ketika menghadapi masalah yang tidak dikehendaki. Oleh karena itu, sangat penting bagi kita untuk berusaha mencari solusi yang bisa mengokohkan bangunan keluarga kita dari hempasan arus zaman yang serba menggelisahkan.

Membangun sakinah dalam keluarga, memang tidak mudah. Ia merupakan bentangan proses yang sering menemui badai. Untuk menemukan formulanya pun bukan hal yang sederhana. Kasuskasus keluarga yang terjadi di sekitar kita dapat menjadi pelajaran penting dan menjadi motif bagi kita untuk berusaha keras mewujudkan indahnya keluarga sakinah di rumah kita.

Kantor urusan agama (KUA) Kecamatan Panjalu merupakan lembaga yang telah aktif melaksanakan program bimbingan pra nikah di Panjalu, Bimbingan yang dikhususkan untuk calon 
pengantin ini dilaksanakan setiap hari. Pasangan yang mendapatkan Bimbingan PraNikah jumlahnya menyesuaikkan calon pengantin yang sebelumnya telah mendaftarkan diri ke KUA. Bagaimanakah poses pelaksanaan bimbingan nikah bagi calon pengantin dalam rangka membentuk keluarga sakinah serta apa yang telah dilakukan, layak untuk menjadi bahan kajian.

Kebanyakan kasus perceraian yang terjadi sekarang ini, disebabkan oleh faktor kurangnya rasa pengertian antara suami istri dan komunikasi yang kurang lancar atau tidak adanya keterbukaaan antara pasangan suami istri. Dengan adanya program bimbingan pra nikah inilah pemerintah daerah, khususnya daerah panjalu ingin menekan angka perceraian yang telah banyak terjadi. baik di panjalu sendiri atau di Kota-Kota lainnya. Kesadaran yang dimiliki oleh pasangan suami istri dalam memahami hak dan tanggung jawabnya menjadi tolok ukur keberhasilan program ini. Menyadari akan kenyataan inilah, maka penulis terdorong untuk mengadakan penelitian dengan judul "Bimbingan Pra Nikah dalam mbentukan keluarga sakinah".

\section{LANDASAN TEORI}

Kata bimbingan ialah terjemahan dari bahasa Inggris yaitu "guidance". Guidance berasal dari kata kerja "to guide" yang artinya menunjukkan, memberi jalan atau menuntun orang lain ke arah yang bermanfaat bagi hidupnya di masa kini dan masa mendatang. Bimbingan merupakan bantuan yang diberikan kepada seseorang (individu) atau sekelompok orang yang mereka itu dapat berkembang menjadi pribadipribadi yang mandiri. Bimbingan juga berarti proses bantuan atau pertolongan yang diberikan oleh pembimbing kepada terbimbing agar individu yang terbimbing mencapai perkembangan yang optimal. Menurut Prayitno, bimbingan adalah proses pemberian bantuan yang dilakukan oleh orang yang ahli kepada seorang atau beberapa orang individu, baik anak-anak, remaja, maupun dewasa; agar orang yang dibimbing dapat mengembangkan kemampuan dirinya sendiri dan mandiri; dengan memanfaatkan kekuatan individu dan sarana yang ada dan dapat dikembangkan; berdasarkan norma-norma yang berlaku.

Dari beberapa uraian diatas tentang definisi bimbingan, dapat disimpulkan bahwa bimbingan adalah proses bantuan yang diberikan oleh orang yang ahli kepada seseorang atau kelompok agar individu dapat mengetahui kemampuan atau bakat minatnya serta dapat mengembangkan potensipotensi yang dimilikinya secara maksimal. Kebanyakan orang juga mengaitkan bimbingan dengan konseling, perlu diingat bahwa bimbingan dan konseling berbeda. Bimbingan diberikan kepada seseorang atau kelompok yang belum mempunyai masalah, bimbingan dilakukan sebagai pencegah masalah yang akan timbul. Sedangkan konseling diberikan kepada seseorang yang telah memiliki masalah dan dapat dipecahkan dan diselesaikan masalahnya dengan proses konseling.

Bimbingan pranikah adalah proses pemberian bantuan terhadap individu agar dalam menjalankan pernikahan dan kehidupan rumah tangga bisa selaras dengan ketentuan dan petunjuk Allah sehingga, dapat mencapai kebahagiaan hidup dunia dan akhirat. Bimbingan memiliki fungsi preventif yaitu lebih bersifat mencegah agar sesuatu tidak terjadi, sesuai asal katanya yaitu "prevent". Artinya mencegah terjadinya / munculnya problem pada diri seseorang. Pertama UnsurUnsur Bimbingan pranikah Dalam memudahkan proses bimbingan, diperlukan unsur-unsur yang mendukung terlaksananya pelaksanaan bimbingan pranikah tersebut. Unsur-unsur bimbingan pranikah adalah komponen-komponen yang selalu ada dalam kegiatan bimbingan pranikah diantaranya yakni subjek bimbingan pranikah, Objek bimbingan pranikah, materi bimbingan pranikah, metode bimbingan pranikah dan media bimbingan pranikah. Kedua Prosedur Pelayanan Pernikahan Sebelum seseorang menjalani pernikahan maka mereka harus melewati prosedur sebelum melangkah ke pernikahan. Calon pengantin harus melengkapi persyarakatan KUA:

1) Surat keterangan untuk nikah (N-1) dari kelurahan/desa; 
2) Kutipan akta kelahiran atau surat kenal lahir, atau surat keterangan asal-usul calon mempelai (N2) dari kelurahan/desa.

3) Surat persetujuan kedua calon mempelai (N-3)

4) Surat keterangan tentang orang tua (N-4) dari kelurahan/desa.

5) Izin tertulis orang tua bagi yang belum berusia 21 tahun (N-5).

6) Pas foto masing-masing $2 \times 3$ sebanyak 4 lembar.

7) Dispensasi dari pengadilan bagi calon suami yang belum berumur 19 tahun dan bagi calon istri yang belum berumur 16 tahun.

8) Izin dari atasannya/kesatuannya bagi anggota TNI/Polri.

9) Izin dari pengadilan bagi suami yang hendak beristri lebih dari seorang.

10) Akta cerai atau kutipan buku pendaftaran talak/buku pendaftaran cerai bagi mereka yang bercerai.

Keluarga merupakan sebuah institusi terkecil di dalam masyarakat yang berfungsi sebagai wahana untuk mewujudkan kehidupan yang tenteram, aman, damai dan sejahtera dalam suasana cinta dan kasih sayang diantara anggotanya. Suatu ikatan hidup yang didasarkan karena terjadinya pernikahan, juga bisa disebabkan karena persusuan atau muncul perilaku pengasuhan. Oleh karena itu, masyarakat adalah himpunan dari beberapa keluarga. Baik buruknya sebuah masyarakat sangat bergantung kepada baik buruknya keluarga.

Apabila dalam suatu masyarakat banyak terwujud rumah tangga yang harmonis (bahagia dan damai) maka masyarakat itu akan stabil tenang, tenteram, damai, sejahtera dan bahagia. Sebaliknya jika dalam suatu masyarakat banyak terdapat rumah tangga yang berantakan, maka masyarakat itu juga akan goncang, tidak tenang dan tidak aman.

\section{Keluarga sakinah}

Keluarga adalah kumpulan beberapa orang yang hidup dalam satu rumah tangga yang diikat oleh ikatan pernikahan yang sah dan bertujuan untuk memelihara keturunan. Keluarga juga merupakan persekutuan hidup yang terkecil dari suatu masyarakat atau bangsa secara keseluruhan.

a. Ciri ciri keluarga sakinah

Keluarga sakinah adalah keluarga yang senantiasa mengembangkan kemampuan dasar fitrah kemanusiaannya, dalam rangka menjadikan dirinya sendiri sebagai manusia yang memiliki rasa tanggung jawab atas kesejahtraan sesama manusia sehingga anggota keluarga merasa aman tentram dan bahagia. Adapun ciri keluarga sakinah mencakup hal hal sebagai berikut:

1) Berdiri diatas pondasi keimanan yang kokoh

2) Menunaikan misi ibadah dalam kehidupan

3) Mentaati ajaran agama

4) Saling mencintai dan menyayangi

5) Saling menjaga dan menguatkan dalm kebaikan

6) Saling memberikan yang terbaik untuk pasangan

7) Musyawarah menyelesaikan permasalahan

8) Membagi peran secara berkeadilan

9) Kompak mendidik anak anak

10) Berkontribusi untuk kebaikan masyarakat, bangsa dan negara

b. Pembentukan keluarga sakinah

Keluarga sakinah adalah keluarga yang dibina atas pernikahan yang sah, mampu hajat hidup spritual dan material secara layak dan seimbang diliputi suasana kasih sayang antara 
anggota keluarga dan lingkungannya dengan selaras, serasi, serta mampu mengamalkan, menghayati dan memperdalam nilai-nilai keimanan, ketaqwaan dan akhlaq mulia.

Beberapa upaya yang perlu ditempuh guna mewujudkan tercapainya keluarga sakinah sebagai berikut:

1) Mewujudkan harmonisasi hubungan antara suami-istri Cinta tanpa keharmonisan akan mengalami banyak hambatan. Adapun upaya mewujudkan harmonisasi hubungan suamiistri dapat dicapai melalui:
a) Saling pengertian
b) Saling menerima kenyataan
c) Saling melakukan penyesuaian diri
d) Saling memupuk rasa cinta
e) Saling melaksanakan asas musyawarah
f) Saling memaafkan

2) Membina hubungan antara anggota keluarga dengan lingkungan. Keluarga dalam lingkup yang lebih besar tidak hanya terdiri dari ayah, ibu dan anak, akan tetapi menyangkut hubungan persaudaraan yang lebih besar lagi, baik hubungan antara anggota keluarga maupun hubungan dengan lingkungan masyarakat.

Sebagaimana penjelasan di atas, maka pembentukan keluarga sakinah sangatlah penting. Pembentukan tersebut adalah upaya atau cara pengelolaan untuk mencapai tujuan dalam mewujudkan keluarga sejahtera, rasa cinta dan kasih sayang sehingga tercipta rasa damai dan aman dalam sebuah keluarga, serta memperoleh kehidupan lebih baik di dunia dan di akhirat.

\section{METODE PENELITIAN}

Metode yang digunakan dalam penelitiaian ini adalah metode penelitian kualitatif. Metode penelitian kualitatif adalah penelitian yang menghasilkan data yang dideskrifsikan berupa kata-kata tertulis atau lisan dari orang-orang dan perilaku yang diamati. Menurut Nasution mengatakan bahwa penelitian kualitatif pada hakekatnya adalah mengamati orang dalam lingkungan hidupnya, berinteraksi dengan mereka, berusaha memahami dengan bahasa dan tafsiran mereka tentang fenomena sekitarnya. Tujuan dari metode penelitian kualitatif adalah bermaksud untuk memperoleh gambaran secara mendalam tentang Bimbingan Pranikah di Kecamatan Panjalu Kabupaten Ciamis.

Untuk mencapai tujuan tersebut peneliti melakukan pendekatan yang menuju arah fenomenalogis. Pendekatan fenomenalogis dianggap sebagai cara pendekatan dan gaya berfikir, dalam pendekatan fenomenalogis ini sering diungkapkan bahwa "jika saya mengetahui tentang dunia, saya mengetahuinya dari sudut pandang saya yang khas atau berdasarkan pengalaman saya tentang dunia". Jadi metode ini adalah suatu metode yang digunakan untuk memaparkan atau menjelaskan secara teoritis dan sistematis dari seluruh data yang diperoleh, sehingga informasi yang diterima benar-benar obyektif.

\section{HASIL DAN PEMBAHASAN}

\section{Bimbingan Pranikah di KUA Kecamatan Panjalu}

Kantor Urusan Agama Kecamatan (KUA) Panjalu berusaha mewujudkan pernikahan yang bahagia serta membentuk keluarga atau rumah tangga yang dibangun bisa utuh, kokoh dan jauh dari masalah yang menyebabkan perceraian sehingga menjadi keluarga yang sakinah mawadah warahmah. Dari dasar inilah KUA Kecamatan Panjalu menyelenggarakan bimbingan pernikahan bagi calon pengantin. 


\section{Tahap Perencanaan Bimbingan Pranikah}

Pra pelaksanaan atau perencanaan merupakan bagian yang penting dari langkah suatu pola pengajaran. Setiap usaha apapun, akan dapat berjalan secara efektif dan efisien, jika sebelumnya sudah direncanakan secara matang. Karena perencanaan secara matang dalam penyelenggaraan segala kegiatan akan berjalan lebih terarah dan teratur. Di samping itu perencanaan juga memungkinkan dipilihnya tindakan yang sesuai dengan situasi dan kondisi.

Analisis dapat dilakukan pada pra pelaksanaan bimbingan pranikah di KUA Kecamatan Panjalu yaitu dengan masing-masing calon pengantin sebelum melakukan bimbingan pernikahan harus memenuhi beberapa prosedur diantaranya:

a. Calon pengantin mendaftarkan diri ke KUA pada H-15 hari kerja;

b. Calon pengantin mengisi formulir pendaftaran yang telah tersedia di KUA Kecamatan Panjalu;

c. Semua persyaratan dilengkapi oleh calon pengantin, calon pengantin datang kekantor kelurahan/kantor desa untuk mendapatkan surat keterangan untuk nikah (N1), surat keterangan asal usul (N2), surat persetujuan (N3), surat keterangan orang tua (N4), akta pengadilan agama bagi yang berstatus duda/janda cerai, surat keterangan kematian suami/istri (N6) bagi yang berstatus duda/janda cerai dan surat pengantar ke Puskesmas untuk memperoleh Imunisasi Tetanus Texolt (TT) dan diserahkan kepada petugas KUA untuk pemeriksaan data atau crosscheck data;

Tahapan sebelum melaksanakan bimbingan pranikah ini telah sesuai dengan yang telah ditetapkan oleh Kementerian Agama. Pasangan yang menjadi bahan data mengungkapkan tahapan sebelum bimbingan pranikah demikian sama seperti yang diungkapkan oleh pegawai KUA Kecamatan Panjalu. Terdapat kesamaan antara jawaban pasangan yang telah melaksanakan bimbingan pranikah dengan pegawai KUA artinya tahapan atau proses pra pelaksanaan bimbingan pranikah di KUA Kecamatan Panjalu telah berjalan dengan baik.

Bimbingan pranikah bagi calon pengantin yang diselenggarakan KUA Kecamatan Panjalu, merupakan suatu pemberian bantuan kepada calon pengantin yang dilakukan secara sistematis dalam memecahkan masalah, dan pemberian informasi seputar pernikahan yang akan dihadapi oleh pasangan calon pengantin. Tujuan terselenggaranya bimbingan ini adalah agar calon pengantin memahami dan mengerti hakikat dan arti pernikahan sehingga dapat terwujud keluarga yang sakinah, mawaddah dan warohmah. Selain itu tujuan bimbingan pernikahan bagi calon pengantin yang dilaksanakan di KUA Kecamatan Panjalu juga untuk membentengi calon pengantin yang akan mengalami perubahan psikologis karena akan hidup bersama, agar menerimanya dengan penuh kerelaan dan ketenangan dalam mengarungi bahtera rumah tangga, beradaptasi dan mengambil manfaat dari apa dialaminya dalam rumah tangganya dikemudian hari.

2. Bentuk bimbingan pranikah

Adapun bentuk Bimbingan pranikah di Kantor Urusan Agama Kecamatan Panjalu sebagai berikut:

a. Pembinaan secara individual

Bentuk pembinaan ini, berupa pemberian nasehat yang diberikan secara individu dan langsung bertatap muka antara pembina dan klien. Pembinaan keluarga sakinah pada pasangan, biasanya dilakukan dengan cara permasalahan yang dihadapi. Misalnya dalam hal ini calon pengantin hanya ada satu pasangan saja berarti pembinaannya dilakukan secara individual. 


\section{b. Pembinaan secara kelompok}

Pembinaan tentang keluarga sakinah pada pasangan juga dilakukan secara kelompok. Seperti pembinaan melalui bimbingan pranikah calon pengantin secara berkelompok, Misalnya pada waktu itu calon pengantinnya ada banyak, maka dilakukan pembinaan secara bersama-sama. Setiap yang dibina diharapkan mampu melakukan komunikasi timbal balik dengan yang lainnya, melakukan hubungan interpersonal satu sama lain dan bergaul melalui kegiatan-kegiatan yang bermanfaat untuk peningkatan pembinaan keluarga. Dalam hal ini, narasumber mengarahkan minat dan perhatian calon pengantin tentang hidup bersama dan saling tolong menolong dalam memecahkan permasalahan bersama yang berkaitan dengan kepentingan mereka bersama.

3. Pelaksanaan bimbingan pranikah

a. Pembimbing dalam bimbingan pranikah

Secara keilmuan akademisi pembingbing harus mempunyai wawasan pengetahuan ilmu yang luas, serta harus memiliki pengalaman dalam bidang nya khusus nya dalam bidang ke agamaan, jadi dari segi professional pembimbing mempunyai kompetensi yang seimbang antara teoritik dan praktik. Pembingbing pranikah di kecamatan Panjalu disebut juga dengan narasumber, dilihat dari segi akademisi para pembimbing di KUA Kecamatan panjalu adalah sarjana, yang mengerti tentang pernikahan dan memiliki jam terbang yang banyak dalam penyampaian materi tentang pernikahan. Pembingbing dalam proses bimbingan pranikah di Kecamatan panjalu terdiri dari kepala KUA Panjalu, Bimas kabupaten Ciamis, Ketua kemenag Kabupaten Ciamis, dan dari bidang kesehatan oleh dokter puskesmas kecamatan panjalu.

b. Terbimbing (calon pengantin) dalam bimbingan pranikah

Pelaksanaan bimbingan pranikah di KUA Panjalu lebih efektif bimbingan kelompoknya dari pada bimbingan individu, oleh krena itu peneliti hanya meneliti bimbingan secara kelompok saja, adapun pada saat pelaksanaan bimbingan pranikah kelompok ada 10 pasangan lebih yang mengikuti pelaksanaan bimbingan pranikah yang dilaksanakan pada tanggal 30-31 Juli 2018. Dan penulis mewawancarai 3 pasangan sebagai sampel dalam penelitian ini.

c. Materi bimbingan pranikah

Dari hasil penelitan dilapangan penulis melihat bahkan mengikuti kegiatan bimbingan pranikah yang di laksanakan KUA Kecamatan Panjalu. Dan menulis apa yang disampaikan, adapun materi yang disampaikan adalah: 1) Membangun landasan keluarga sakinah 2) Dinamika perkawinan 3) Kesehatan keluarga 4) Generasi berkualitas 5) Ketahanan keluarga dalam menghadapi tantangan masa kini 6) Mengelola konflik keluarga.

4. Metode bimbingan pranikah

Metode pranikah dilakukan selama 2 hari dimulai dari jam 08:15 - 15:15, pembimbing memberikan bekal kepada calon pengantin yang akan menjalani kehidupan bahtera rumah tangga, dimaksudkan agar mereka memahami secara benar peran masing masing dalam menciptakan kebahagiaan hidup dalam rumah tangganya. Adapun metode yang digunakan dalam bimbingan pranikah KUA Kecamatan Panjalu adalah: Ceramah, Diskusi, Tanya jawab, Study kasus (Simulasi).

Dari semua uraian tentang proses pelaksanaan bimbingan pranikah di KUA Kecamat Panjalu di atas, mulai dari persiapan sampai dengan pelaksanaan maka penulis berkesimpulan bahwa pelaksanaan bimbingan konseling pranikah sudah berjalan cukup baik, walaupun dari beberapa segi perlu peningkatan, akan tetapi semuanya bisa berjalan dengan baik. 


\section{Analisis Dampak bimbingan pranikah di KUA Kecamatan Panjalu}

Bimbingan pranikah diselenggarakan dalam rangka mempersiapkan calon pengantin, baik dari segi pisik atau psikis. Sebagaimana dikatakan ketua kementrian agama kabupaten Ciamis saat mengisi sambutan sebelum di laksanakannya bimbingan pranikah yakni untuk meningkatkan kesejahteraan dan kekuatan keluarga, maka diperlukan ilmu pengetahuan tentang berbagai aspek yang menyangkut kehidupan keluarga, baik interaksi pola antar individu dalam keluarga maupun pola interaksi antar keluarga dalam sistem sosial yang lebih besar.

Dampak bimbingan pranikah dalam membentuk keluarga sakinah di KUA Kecamatan Panjalu, yakni adanya persiapan dari calon pengantin terutama segi fisik terkait dengan materi yang disampaikan, pasangan calon pengantin sebelum mengikuti bimbingan banyak hal yang tidak mereka ketahui tetapi berdasarkan hasil wawancara yang penulis lakukan bahwa para calon pengantin mengaku bimbingan pranikah ini sangat bermanfaat untuk mereka. Karena banyak pengetahuan yang sebelumnya mereka tidak ketahui setelah mengikuti bimbingan menjadi mengerti, serta mereka ingin senantiasa berusaha semaksimal mungkin untuk meningkatkan kualitas perkawinan serta mewujudkan keluarga bahagia dan sejahtera, kekal menurut tuntunan Islam.

Berdasarkan data peserta Bimbingan pranikah khusus calon pengantin dengan persentase pekerjaan, umur, serta pendidikan yang rata-rata hanya lulusan SMP sebanyak 40\% lulusan SMA $55 \%$ dan untuk lulusan S1 hanya 5\%, tetapi hal ini memungkinkan untuk sebuah keluarga mewujudkan keluarga sakinah karena calon pengantin yang mengikuti proses bimbingan pranikah di KUA Kecamatan Panjalu ini telah mempunyai pekerjaan walaupun persentase terbesar yakni dari swasta sebanyak 75\%. Keluarga sakinah tidak datang begitu saja, tetapi harus diperjuangkan untuk kehadirannya maka melalui bimbingan pranikah inilah KUA Kecamatan Panjalu ingin mewujudkan keluarga yang tentran dan damai kelurga yang sakinah, mawadah wa rahmah.

\section{Faktor pendukung dan penghambat bimbingan pranikah di KUA Kecamatan Panjalu}

1. Faktor pendukung pelaksanaan bimbingan pranikah

Dari pernyataan Bapak H. Idi ketua KUA Kecamatan Panjalu dapat diuraikan bahwa faktor yang menunjang berjalannya layanan bimbingan pranikah yang ada di KUA Kecamatan Panjalu adalah sebagai berikut;

a. Antusiasme peserta

Program bimbingan pranikah cukup diminati oleh calon pasangan Pengantin, Semua yang hadir dalam program ini menyimak dengan baik dan rasa ingin tahunya cukup, pertanyaan yang diajukan peserta tidak terlalu banyak, mungkin karena mereka masih malumalu bertanya mengenai persoalan pernikahan. Kecuali saat penyampaian materi kesehatan reproduksi, Calon pasangan ynag tidak hadir pun ada dengan alasan tidak dapat izin dari tempat kerja.

b. Pembimbing yang cukup kompeten

Pembimbing yang berkompeten dibidangnya adalaah pembimbing yang memiliki wawasan yang luas, khususnya tentang materi yang berhubungan dengan pelaksananaan bimbingan pranikah dan keluarga sakinah pembimbing langsung dari kementrian agama kabupaten Ciamis dan bimas kabupaten Ciamis, materi kesehatan reproduksi pemateri adalah dokter yang berasal dari Puskesmas Kecamatan.

c. Metode penyampaian yang sangat sederhana

Metode yang disampaikan oleh pembimbing menggunakan metode ceramah (tatap muka), tanya jawab dan peraktek berdasarkan pengalaman pembimbing atau orang lain yang 
dapat disesuaikan sebagai pegangan dalam tindakan masing-maisng individu. Dengan bahasa yang mudah dimengerti oleh peserta, bimbingan pranikah membuat suasana bimbingan pranikah tenang dan nyaman.

2. Faktor Penghambat pelaksanaan bimbingan pranikah

Setiap program pasti ada faktor pendukung dan faktor penghambatnya. Dari hasil wawancara peneliti dengan Ketua KUA yang menjadi sampel faktor penghambat terlaksananya bimbingan pranikah, berikut kutipan wawancara peneliti dengan ketua KUA Kecamatan Panjalu.

"Kalau hambatan itu pasti ada misal petugas menargetkan pembinaan calon pengantin tetapi jumlahnya tidak sesuai dengan yang ditargetkan. Dikarenakan peserta bimbingan pranikah masih ada yang berkerja dan masih ada yang diluar kota".

"Hambatan yang dialami dalam bimbingan pranikah di KUA Kecamatan Kedondong mengenai peserta bimbingan yang kadang-kadang tidak hadir dan suka telat hadir ke KUA. Ruang balai nikah yang digunakan terkadang tidak dapat menampung semua peserta bimbingan".

Dapat diuraikan bahwa faktor penghambat dalam pelaksanaan bimbingan pranikah di KUA Kecamatan Panjalu yaitu:

a. Tempat tinggal calon pengantin

Diantara para calon pengantin yang akan mengikuti bimbingan pranikah jauh dari kawasan Kantor Urusan Agama Kecamatan Panjalu. Ada juga yang sedang bekerja di luar kota dan tidak dapat izin dari atasannya untuk bisa mengikuti bimbingan pranikah

b. Keterbatasan wawasan para peserta

Keterbatasan dari wawasan calon pengantin yang kadangkala mereka sulit memahami materi bimbingan yang disampaikann oleh narasumber, rasa malu pera calon pengantin untuk bertanya dan aktif dengan narasumber.

c. Kurang disiplinnya peserta.

Peserta bimbingan pranikah datang tidak tepat waktu, dan lebih mengutamakan datang pada saat pengecekan data. Dan ada juga yang hanya ikut setengah hari, karena alasan pekerjaan atau hanya di beri izin setengah hari oleh atasannya.

d. Materi bimbingan pranikah yang kurang lengkap

Tidak adanya materi psikologi pernikahan dalam proses bimbingan pranikah karena pemateri khusus dibidang psikologi belum ada. Menurut peneliti materi psikologi ini penting untuk peserta bimbingan pranikah karena didalam materi ini calon pengantin lebih mengerti cara menetralkan emosi, memperlakukan pasangan dengan sebaiknya, membina keluarga yang sakinah, membimbing anak menjadi akhlak yang baik. Semua materi ini diperlukan calon pengantin sebagai pengetahuan mereka dalam menjalani kehidupan rumah tangganya nanti.

e. Posisi media

Posisi media saat penyampaian materi oleh narasumber tidak terlihat oleh semua peserta, dikarenakan posisi media berada di samping para peserta jadi tidak semua peserta bisa melihat media yang disampaikan oleh pemateri.

Keberhasilan yang telah dicapai dari program ini adalah adanya kesadaran dari pasangan, akan hak dan tanggung jawab sebagai seorang suami dan istri. sehingga dalam kehidupan berumah tangga terbentuk sikap saling pengertian, serta saling menghargai. karena dari kebanyakan kasus perceraian yang terjadi sekarang ini, salah satunya disebabkan oleh faktor kurangnya rasa pengertian antara suami istri dan komunikasi yang kurang lancar, atau tidak adanya keterbukaaan antara pasangan suami istri. Kesadaran yang dimiliki oleh 
pasangan suami istri dalam memahami hak dan tanggung jawabnya menjadi tolok ukur keberhasilan program ini.

\section{KESIMPULAN}

Berdasarkan hasil penelitian tentang bimbingan pranikah dalam membentuk keluarga sakinah di KUA Kecamatan Panjalu Kabupaten Ciamis, maka peneliti dapat mengambil kesimpulan bahwa Bimbingan Pranikah dalam membentuk keluarga Sakinah di KUA Kecamatan Panjalu terbagi menjadi dua bentuk yaitu bimbingan secara individu dan kelompok, akan tetapi bimbingan pranikah individu tidak efektif di karenakan calon pengantin tidak langsung mendaftar ke KUA akan tetapi di urus langsung oleh petugas dari desa yaitu (Petugas Pembantu Pencatat Nikah) P3N, adapun pelaksanaannya ada dua tahap, yaitu tahap pra pelaksanaan dan tahap pelaksanaan.

Dampak bimbingan pranikah dalam membentuk keluarga sakinah di KUA Kecamatan Panjalu berdasarkan hasil wawancara yang penulis lakukan bahwa para calon pengantin mengaku bimbingan pranikah ini sangat bermanfaat untuk mereka. Karena banyak pengetahuan yang sebelumnya mereka tidak ketahui setelah mengikuti bimbingan menjadi mengerti, serta mereka ingin senantiasa berusaha semaksimal mungkin untuk meningkatkan kualitas perkawinan serta mewujudkan keluarga bahagia dan sejahtera, kekal menurut tuntunan Islam.

1. Faktor pendukung bimbingan pranikah dalam membentuk keluarga sakinah
a. Antusiasme peserta
b. Pembimbing yang cukup kompeten
c. Metode penyampaian yang sangat sederhana

2. Faktor penghambat bimbingan pranikah dalam membentuk keluarga sakinah

a. Tempat tinggal calon pengantin yang lumayan jauh dari KUA

b. Keterbatasan wawasan para peserta

c. Kurang disiplinnya peserta.

d. Materi bimbingan pranikah yang kurang lengkap

e. Posisi media

Setelah pembahasan penelitian jurnal ini, sesuai harapan peneliti agar

Jurnal ini dapat bermanfaat bagi semua pihak, maka peneliti ingin menyampaikan saran- saran sebagai berikut:

1. Perlunya sosialisasi dari pihak terkait khususnya Kementrian Agama sebagai mitra KUA dalam mensosialisasikan kursus pra-nikah yang meliputi bimbingan pranikah dikarenakan masih banyaknya masyarakat yang belum mengikuti kursus tersebut.

2. KUA hendaknya meningkatkan kompetensi konselor/penasihat perkawinan dengan menambahkan penasihat psikolog agar dapat mengoptimalkan pelaksanaan bimbingan pranikah

3. Tokoh Agama hendaknya dalam berda'wah tidak hanya menyampaikan masalah-masalah ubudiyah, fiqhiyah akan tetapi membahas masalah keluarga, bagaimana membina rumah tangga menjadi sebuah rumah tangga yang sakinah mawaddah wa rahmah.

4. Masyarakat diharapkan mendukung KUA dalam penyelenggaran kursus calon pengantin dan turut berperan serta untuk bersosialisasi pada masyarakat mengenai pembinaan keluarga sakinah mawaddah wa rahmah.

5. Kepada para calon pengantin yang mengikuti bimbingan pranikah hendaknya bisa disiplin dalam mengikuti kegiatan tersebut dan juga mengikuti sampai selesai 


\section{DAFTAR PUSTAKA}

Arifin, Pedoman Pelaksanaan Bimbingan dan Penyuluhan Agama (Jakarta: PT, Golden Trayon Press, 1998)

Al-Shabagh, Mahmud, Tuntunan Keluarga Bahagia Menurut Islam (PT. Remaja Rosda Karya, 1994)

Abdul Rahman Ghozali, Fiqh Munakahat, (Jakarta: Kencana, 2003)

Amir Syarifuddin, 2003, Garis-Garis Besar Fikih, Bogor: Kencana

Faqih, Aunur Rahim Bimbingan Konseling dalam Islam Yogyakrta 1996

Ali Ahmad Al-Jurjawi, Hikmah Al-Tasyri wa Falsafatuh (Falsafah dan Hikmah Hukum Islam),

Andi Syahraeni, Bimbingan Keluarga Sakinah

Akilah Mahmud, Keluarga Sakinah Menurut Pandangan Islam,

Departemen Negara RI, Bahan penyuluhan Hukum (Jakarta: Departemen Agama RI, 1999/2000)

Dep Dikbud, Kamus Besar Bahasa Indonesia, (Jakarta Balai Pustaka, 1994) cet ke, Edisi kedua

Direktorat bina KUA dan keluarga sakinah, fondasi keluarga sakinah, (Bimas Kmenag RI 2017)

Departemen Pendidikan dan Kebudayaan, Kamus Besar Bahasa Indonesia (Jakarta: Balai Pustaka, 1996)

Emzir, Metodologi Penelitian Kualitatif: Analisis Data, (Jakarta: PT Raja Grafindo Persada, 2012,)

Hamdani Bakran Adz Dzaky, Psikoterapi Konseling Islam, Cet. I (Yogyakarta: Fajar Pustaka Baru, 2001)

https://id.wikipedia.org/wiki/Pernikahan

Kanwil Dep. Agama, Pedoman Keluarga bahagia Sejahtera

Lexi J. Meleong, Metode Penelitian Kualitatif (Bandung: Remaja Rosda Karya, 1994)

Mochamad bugi/articles/baitul muslim,

M. Quraish Shihab, Perempuan (Cet. I; Jakarta: Lentera Hati, 2005),

Nasaruddin, Latif, Ilmu Perkawinan Problematika Seputar Keluarga dan Rumah Tangga, (Bandung: Pustaka Hidayah, 2001.)

Prayitno, Erman Amti, Dasar-dasar Bimbingan \& Konseling (Jakarta: Rineka Cipta, 2013)

Undang-Undang RI No 1 Tahun 1974 Tentang Perkawinan (Bandung: Citra Umbara, 2012)

Walgito, Bimo, Bimbingan dan Konseling Perkawinan, (Yogyakarta: Andi, 2004.)

Amini, Ibrahim. Bimbingan islam untuk kehidupan suami istri. Albayan. Bandung: 1996

Aisyah, PP. Tuntunan Menuju Keluarga Sakinah, Yogyakarta. PP. Aisyah

Al-Shabagh, Mahmud, Tuntunan Keluarga Bahagia Menurut Islam PT. Remaja Rosda Karya, 1994

Walgito, Bimo. Bimbingan Dan Konseling Perkawinan yayasan penerbitan fakultas psi kologi

UGM, 1994 